\title{
The Interaction of Bovine Serum Albumin with Trimeric (Methyldodecylbis [2- (Dimethyldodecylammonio) Ethyl] Ammonium Tribromide and Make A Comparison with Corresponding Gemini and Monomeric Surfactants
}

\author{
Yan $\mathrm{Tu}^{1}$, Yazhuo Shang ${ }^{1 *}$, Honglai Liu ${ }^{1}$ and Fei Gao ${ }^{2}$ \\ ${ }^{1}$ School of Chemistry \& Molecular Engineering, East China University of Science and Technology, China \\ ${ }^{2}$ The $2^{\text {nd }}$ Refinery of Fushun Petrochemical Company of Petro china, Fushun, China
}

Received: 制 August 01, 2018; Published: 制 August 08, 2018

*Corresponding author: Yazhuo Shang, School of Chemistry \& Molecular Engineering, East China University of Science and Technology, China, Tel: 86216425 2767; Email: shangyazhuo@ecust.edu.cn

\begin{abstract}
The mixed systems of bovine serum albumin (BSA) and surfactants were widely used in biological, foods, pharmaceutical and cosmetics. In this work, trimeric (methyldodecylbis [2-(dimethyldodecylammonio) ethyl] ammonium tribromide surfactant $\left(\mathrm{C}_{12}-\mathrm{C}_{2}-\mathrm{C}_{12}-\mathrm{C}_{2}-\mathrm{C}_{12} \cdot 3 \mathrm{Br}-\right)$ and Gemini surfactant 1, 2-ethane bis (dimethyldodecylammonium bromide) $\left(\mathrm{C}_{12}-\mathrm{C}_{2}-\mathrm{C}_{12} \cdot 2 \mathrm{Br}\right.$-) were synthesized. And the interaction of trimeric surfactant $\left(\mathrm{C}_{12}{ }^{-}\right.$ $\mathrm{C}_{2}-\mathrm{C}_{12}-\mathrm{C}_{2}-\mathrm{C}_{12} \cdot 3 \mathrm{Br}-$ ), Gemini surfactant $\left(\mathrm{C}_{12}-\mathrm{C}_{2}-\mathrm{C}_{12} \cdot 2 \mathrm{Br}-\right)$ and Monomeric Surfactant (Dodecyl trimethyl ammonium bromide: DTAB) with BSA were explored systematically by surface tension, fluorescence methods dynamic light scattering (DLS). The results suggested that the trimeric surfactants have the greatest effect on BSA unfolding comparing with the corresponding Gemini and monomeric surfactants. Furthermore, $\mathrm{C}_{12}-\mathrm{C}_{2}-\mathrm{C}_{12} \cdot 2 \mathrm{Br}-\mathrm{also}$ have much stronger binding ability with BSA to induce the denaturation of $\mathrm{BSA}$ at lower concentration of $\mathrm{C}_{12}-\mathrm{C}_{2}-\mathrm{C}_{12} \cdot 2 \mathrm{Br}$ - Compared with DTAB. Those results will attribute to understand the physicochemical effect of surfactant architecture on its interaction with biomacromolecules and broaden their potential applications in medicine.
\end{abstract}

Keywords: Bovine Serum Albumin; Trimeric Surfactant; Gemini surfactant; Interaction

Abbreviations: DTAB: Dodecyl Trimethyl Ammonium Bromide; DLS: Dynamic Light Scattering; CMC: Critical Micelle Concentration; CAC: Critical Aggregation Concentration; BSA: bovine serum albumin

\section{Introduction}

Protein is a kind of important biological organisms [1]. Due to the amphiphilic properties of the amino acids, which inducing the binding of surfactants on protein [2]. It is well known that the surfactants-protein system are of significant importance because of their widely used in cosmetic, biological, pharmaceutical, drug delivery systems [3-6]. The surfactants can be used as denaturants to organize the structure of protein which in many cases leads to perturbation of various biological functions of protein [7]. For instance, cationic surfactants can be used as bactericide in various protein systems [8]and Alzheimer's disease due to aggregation of amyloid genic proteins [9]. Therefore, understanding of the nature of protein-surfactant interaction seemed to be essential with respect to the advancement of the fields of pharmaceutical and cosmetic research $[10,11]$. Up to now, the interaction of protein with surfactants has been widely reported. Previous investigations on $\mathrm{BSA} /$ surfactant were mainly focused on the traditional surfactants, Such as DTAB, SDS, and $\mathrm{C}_{12}$ E8 [12-14]. Later, the research showed that Gemini surfactants made a lager effect on proteins as compared with conventional single-chain surfactants [14-18]. Then a large amount of literatures about Gemini surfactant / BSA system were appeared [19-21].

Liu's group [22] investigated the interaction of Gemini surfactants $(12-n-12, n=3,4,6)$ and made a comparison with the traditional single-chain surfactants (DTAB). The results showed that the interaction between BSA and Gemini surfactants increase with the length of spacer groups and the BSA/Gemini surfactants systems is superior to BSA/DTAB system. Up to now, the research of surfactant/BSA system still mainly about Gemini surfactant. However, the oligomeric surfactants have rapidly develop. Gemini surfactant which has many unique properties $[23,24]$ drive people to research the higher oligomeric surfactants, such as trimeric surfactants. However, no relative research about the BSA/ trimeric surfactant complex has been published. Therefore, it's meaningful for us to research the interaction of BSA with trimeric surfactants. Which may broaden the application of novel trimeric surfactants in industry area. In this article, we investigated the interaction of trimeric surfactants with BSA and make a comparison systematically with Gemini surfactant and monomeric surfactants. BSA is widely 
used as a model protein for its structural homology with HSA, low cost, high water solubility, easily available in pure form [25].

It is a kind of globular protein with a relative molecular mass of around 66KD. The primary structure of BSA is composed of 583 amino acid residues and it is characterized by low tryptophan content along with a high content of cysteine, stabilizing a series of nine loops. The tertiary structure is composed of three domains I, II, and III, with each containing two subdomains A and B. The protein BSA contains two tryptophan residues, Trp-134 and Trp-212, and they are located in the hydrophilic subdomain IB and hydrophobic subdomain IIA, respectively [26]. The cationic quaternary ammonium trimeric surfactants which have three hydrophilic head groups and three hydrophobic chains linked by spacer groups were synthesized and characterized. We investigated their interaction with BSA by surface tension, fluorescence methods dynamic light scattering (DLS). Cationic quaternary ammonium trimeric surfactants with hypo toxicity, lower critical micelle concentration, and higher interfacial activity and so on compared with Gemini surfactants, which made it as an alternative to be used in biochemistry. Furthermore, the trimeric surfactants interact strongly with protein molecules and denature them at very low concentrations.

Thus the trimeric surfactants could behave as an efficient denaturant than the common chemical denaturants such as urea, guanidine hydrochloride etc. and in such altered conformational states, protein molecules can readily interact with nonpolar substrates [27]. The further study of interaction of BSA/surfactants is of great significance to deeply understand the interaction principle of surfactant with BSA and promote the development of medicine and food engineering. It can predict that trimeric surfactants has better properties compared with corresponding Gemini surfactants in surfactant/proteins systems. It will also enrich the application of surfactants in the field of biology.

\section{Materials and methods}

\section{Materials}

TheTrimeric(Methyldodecylbis [2-(Dimethyldodecylammonio) Ethyl] Ammonium Tribromide $\left(\mathrm{C}_{12}-\mathrm{C}_{2}-\mathrm{C}_{12}-\mathrm{C}_{2}-\mathrm{C}_{12} \cdot 3 \mathrm{Br}-\right)$ was synthesized according to the methods reported elsewhere [28]. The Gemini surfactant 1, 2-ethane bis (dimethyldodecylammonium bromide) $\left(\mathrm{C}_{12}-\mathrm{C}_{2}-\mathrm{C}_{12} \cdot 2 \mathrm{Br}-\right)$ was synthesized according the paper we have published [29]. DTAB and Bovine serum albumin (BSA, fraction $V$ ) was purchased from Aladdin (Shanghai, China). The structure of BSA, $\mathrm{C}_{12}-\mathrm{C}_{2}-\mathrm{C}_{12}-\mathrm{C}_{2}-\mathrm{C}_{12} \cdot 3 \mathrm{Br}-, \mathrm{C}_{12}-\mathrm{C}_{2}-\mathrm{C}_{12} \cdot 2 \mathrm{Br}$ - and DTAB are shown in scheme1. The ultrapure water was used to prepare the sodium phosphate buffer of $\mathrm{PH}=7.4$ with ionic strength being 0.02 mol-L- 1 by $\mathrm{Na}_{2} \mathrm{HPO}_{4}$ and $\mathrm{NaH}_{2} \mathrm{PO}_{4}$ (Sinopharm Chemical Reagent Co., Ltd). All solutions were prepared using sodium phosphate buffer solution as solvent.
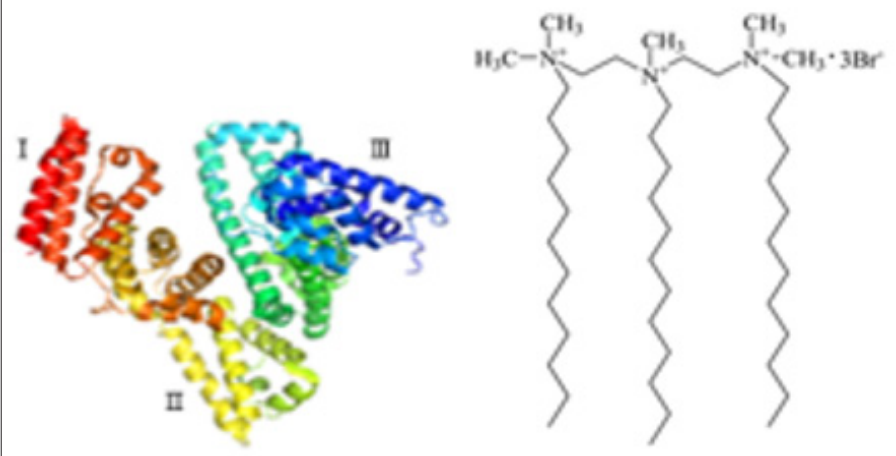

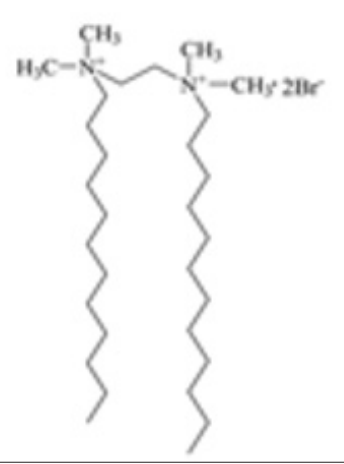

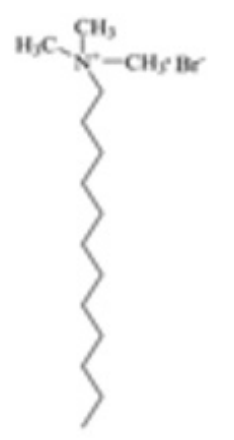

Scheme 1: The structure of BSA, $C_{12}-C_{2}-C_{12}-C_{2}-C_{12} \cdot 3 B r-, C_{12}-C_{2}-C_{12} \cdot 2 B r-$ and DTAB.

\section{Structure and property characterization}

The structures of synthesized surfactants were checked by ${ }^{1} \mathrm{HNMR}$ (Bruker $400 \mathrm{MHz}$ NMR spectrometer, using $\mathrm{CDCl}_{3}$ as solvent). We evaluated the purity of the surfactant by the error $\mathrm{D}$ of the theoretical value and measurements through analyzing of the contents of the elements $\mathrm{C}, \mathrm{H}, \mathrm{N}$ (Elemental analysis, Germany Elemental Corporation) in the surfactants. All the errors D were lower than $5 \%$, which indicating that the purity of surfactants was higher than 95\%. The surface tension and Critical micelle concentration (CMC) were calculated by Wihelmy plate method (Automatic tension apparatus, BZY-2).

\section{Fluorescence spectroscopy}

The fluorescence measurements were obtained by using Hitachi F-4500 fluorescence spectrometer. The sample was measured using a $1 \mathrm{~cm}$ quartz cuvette at $298.15 \mathrm{~K}, 308.15 \mathrm{~K}$ and $318.15 \mathrm{~K}$. The slits of excitation and emission were both fixed at $5.0 \mathrm{~nm}$ and $2.5 \mathrm{~nm}$ respectively in fluorescence measurement. The intrinsic fluorescence of BSA solutions $(1 \mathrm{~g} / \mathrm{L})$ with various surfactant concentrations was measured by fixing the excitation spectra at $280 \mathrm{~nm}$ and the emission spectra ranging from $290 \mathrm{~nm}$ to $400 \mathrm{~nm}$.

\section{Dynamic light scattering (DLS)}

DLS measurements of BSA with different concentrated surfactants were taken by Malvern Nano ZS instrument (Southborough, MA) at $298.15 \mathrm{k}$ with a $173^{\circ}$ backscattering detector and a He-Ne laser of $633 \mathrm{~nm}$. All samples were filtered in a quartz cuvette about $1 \mathrm{ml}$ by $0.22 \mathrm{um}$ microporous filters and keep constant temperature 120s before measurement. The hydrodynamic radii was obtained using the DLS software. 


\section{Results and Discussion}

The surface tension of $\mathrm{C}_{12}-\mathrm{C}_{2}-\mathrm{C}_{12}-\mathrm{C}_{2}-\mathrm{C}_{12} \cdot 3 \mathrm{Br}$ and $\mathrm{C}_{12}-\mathrm{C}_{2}-$ $\mathrm{C}_{12}-\mathrm{C}_{2}-\mathrm{C}_{12} \cdot 3 \mathrm{Br} / \mathrm{BSA}$

The CMC of $\mathrm{C}_{12}-\mathrm{C}_{2}-\mathrm{C}_{12}-\mathrm{C}_{2}-\mathrm{C}_{12} \cdot 3 \mathrm{Br}$ measured by surface tension method are $0.82 \times 10^{-4} \mathrm{~mol} / \mathrm{L}$. The CMC of trimeric surfactants is an order of magnitude lower than the corresponding Gemini surfactant $\mathrm{C}_{12}-\mathrm{C}_{2}-\mathrm{C}_{12} \cdot 2 \mathrm{Br}$. Surface tension is an effective method to study the interaction between protein and surfactants. From figure, it can be seen that the surface tension of complex is lower than the surfactants. Which indicate that the complex is more surface active compared to surfactants. The first break point of the $\mathrm{BSA} /$ surfactant system is the critical aggregation concentration (CAC). After CAC, a more or less constant surface tension region is observed until the protein backbone is saturated by surfactants. The break point is called protein saturation concentration (Cs). After the $\mathrm{C}_{S^{\prime}}$, The surface activity starts to decrease again with the further addition of surfactants and then reach the CMC. The CMC of complex is larger than corresponding pure surfactants due to the binding of surfactants to protein and more surfactants required to saturate surface. The results show that there is a significant interaction between BSA and trimeric surfactant.

\section{Intrinsic fluorescence}

The structure of BSA is sensitive to fluorescence due to tryptophan (Trp) and tyrosine (Tyr) residues. Thus, fluorescence investigations is an effective way to evaluate the interaction of BSA with surfactants [8]. As a result, the interaction of three surfactants with different aggregates with BSA was compared by intrinsic fluorescence method. As shown in (Figures $1 \& 2$ ), the fluorescence intensity does not change significantly at lower surfactants' concentration. With the further increase of the concentration of surfactants, the values of fluorescence intensity reduce drastically. It suggests that the BSA is unfolded gradually while the hydrophobic group (tryptophan) of BSA is exposed to the hydrophilic environment. Fluorescence measurements indicate that the interaction is expected to be mainly electrostatic at lower surfactant concentrations, and when the surfactant concentration increases, hydrophobic interaction plays a major role. Further increase surfactant concentrations, BSA-surfactant interactions are saturated and a subsequent increase in surfactant concentration results in the formation of micelles. Besides, the concentration of trimeric surfactant $\mathrm{C}_{12}-\mathrm{C}_{2}-\mathrm{C}_{12}-\mathrm{C}_{2}-\mathrm{C}_{12} \cdot 3 \mathrm{Br}$ causing BSA conformational changes is much lower than the concentration of Gemini surfactants $\left(\mathrm{C}_{12}-\mathrm{C}_{2}-\mathrm{C}_{12} \cdot 2 \mathrm{Br}\right)$ and monomeric surfactants (DTAB). In addition, we can also see from the comparison of fluorescence curves of three surfactants that when the concentration of surfactants are close to $\mathrm{CMC}$, the conformation of protein can be changed to maximum. As you can see from the figure, the order is $\mathrm{C}_{12}-\mathrm{C}_{2}-\mathrm{C}_{12}-\mathrm{C}_{2}-\mathrm{C}_{12} \cdot 3 \mathrm{Br}>\mathrm{C}_{12}-\mathrm{C}_{2}-\mathrm{C}_{12}-\mathrm{C}_{2}-\mathrm{C}_{12} \cdot 3 \mathrm{Br}^{-}>\mathrm{DTAB}$. The results showed that the trimeric surfactants made a stronger effect on BSA.

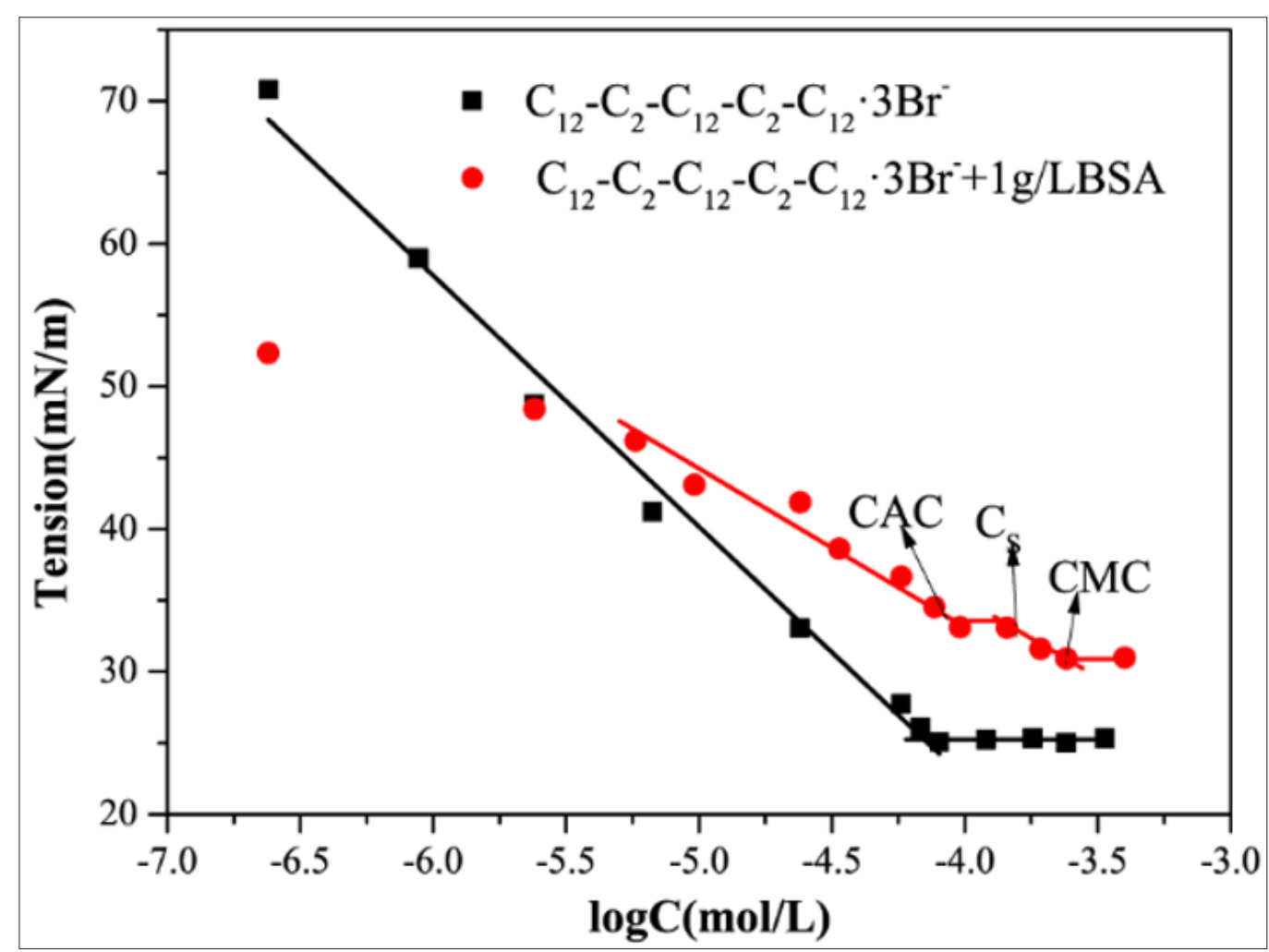

Figure 1: Surface tension curves of $\mathrm{C}_{12}-\mathrm{C}_{2}-\mathrm{C}_{12}-\mathrm{C}_{2}-\mathrm{C}_{12} \cdot 3 \mathrm{Br}-$ and $\mathrm{C}_{12}-\mathrm{C}_{2}-\mathrm{C}_{12}-\mathrm{C}_{2}-\mathrm{C}_{12} \cdot 3 \mathrm{Br}-/ \mathrm{BSA}(1 \mathrm{~g} / \mathrm{L})$ at

$\mathrm{PH}=7.4, \mathrm{~T}=298.15 \mathrm{k}$. 

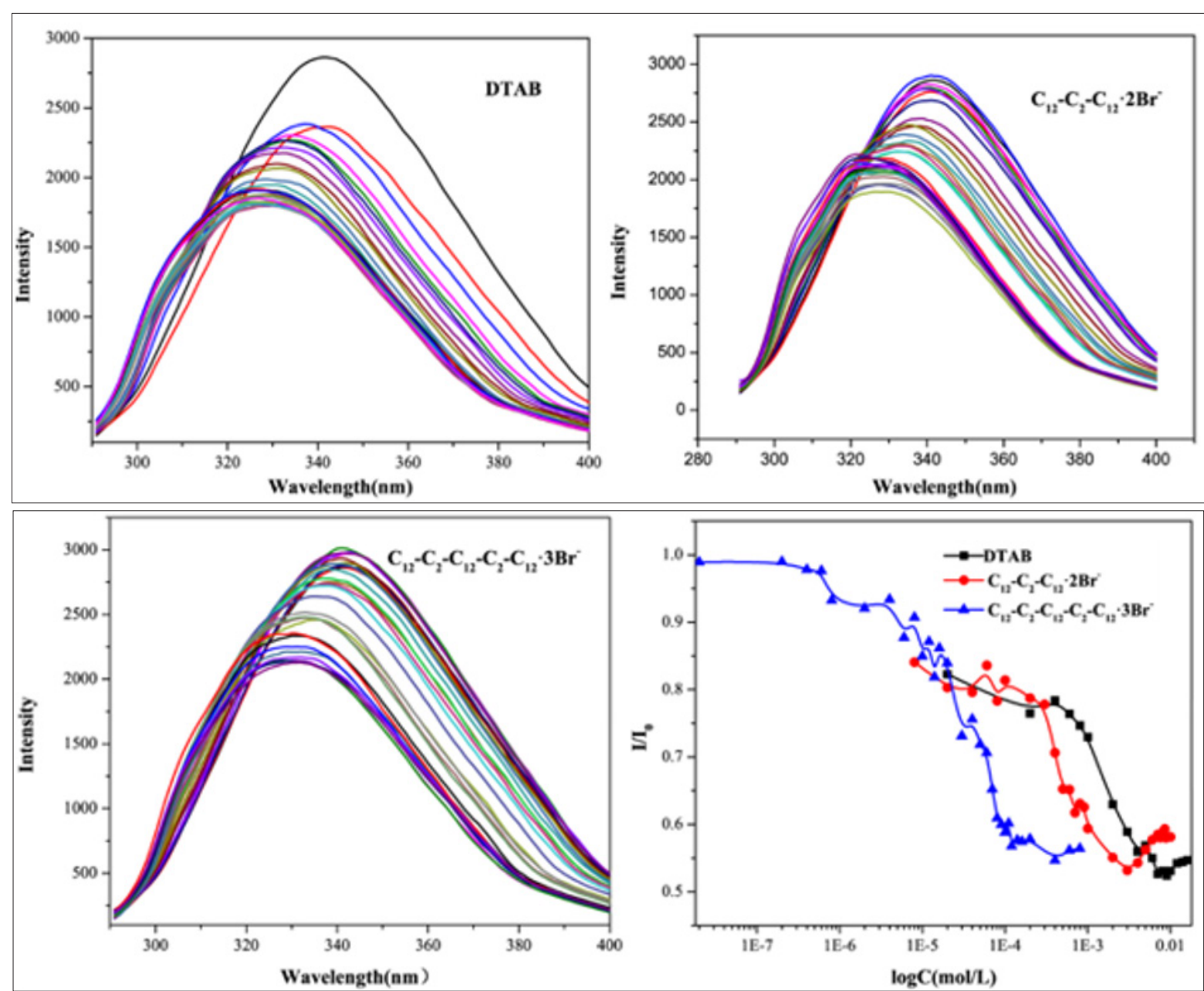

Figure 2: Intrinsic fluorescence of $\mathrm{BSA}(\mathrm{C}=1 \mathrm{~g} / \mathrm{L})$ with various surfactants (DTAB; $\mathrm{C}_{12}-\mathrm{C}_{2}-\mathrm{C}_{12} \cdot 2 \mathrm{Br}-; \mathrm{C}_{12}-\mathrm{C}_{2}-\mathrm{C}_{12}-\mathrm{C}_{2}-\mathrm{C}_{12} \cdot 3 \mathrm{Br}-$ ) at $\mathrm{PH}=7.4$ and $289.15 \mathrm{~K}$.

\section{Dynamic light scattering (DLS)}

Studies have shown that the hydrodynamic diameter of the protein would increase when the surfactants were added into the protein aqueous solution [30]. Due to the hydrophobic interaction between the hydrophobic tail chains of surfactants and the non-polar amino acids on the protein. The hydrophobic amino acids hidden in the protein core can be unfolded, resulting to the denaturation of protein. Therefore, the effect of different surfactants on BSA conformation can be compared by the variation of hydrodynamic radius of BSA/surfactant complexes. It can be seen from the (Figure 3 ) that the hydrodynamic radius $\left(R_{h}\right)$ of the protein changes little at the lower concentration of surfactants. With the further increase of the concentration of surfactants, the hydrophobic interaction between the surfactants and BSA leads to the unfolding of BSA. So that the $\mathrm{R}_{\mathrm{h}}$ increases. Besides, the electrostatic interaction between the surfactants and BSA reduce the electrostatic repulsion among BSA molecules. It also leads to an increase of the $R_{h}$ of samples. As the surfactant concentration is further increased, the surfactant micelles are gradually formed, so that the hydrodynamic radius decrease. DLS studies reveal that the hydrodynamic diameter of BSA increases about 2 times when the protein-surfactant assemblies are formed. It verified that the electrostatic interaction pays an important role of in controlling the overall formation of the BSA-surfactant assembly. It can be seen from the (Figure 3) that the concentration of the $\mathrm{C}_{12}-\mathrm{C}_{2}-\mathrm{C}_{12}-\mathrm{C}_{2}$ $\mathrm{C}_{12} \cdot 3 \mathrm{Br}-$ to denature the BSA is much lower than the corresponding Gemini surfactant $\mathrm{C}_{12}-\mathrm{C}_{2}-\mathrm{C}_{12} \cdot 2 \mathrm{Br}$ and single chain surfactant DTAB, indicating that the trimeric surfactant is much more denatured than the traditional surfactant. This is consistent with the results obtained by intrinsic fluorescence.

\section{Conclusion}

The comparative studies on the interactions of bovine serum albumin (BSA) with cationic trimeric surfactant $\mathrm{C}_{12}-\mathrm{C}_{2}-\mathrm{C}_{12}$ $\mathrm{C}_{2}-\mathrm{C}_{12} \cdot 3 \mathrm{Br}$, Gemini surfactant $\mathrm{C}_{12}-\mathrm{C}_{2}-\mathrm{C}_{12} \cdot 2 \mathrm{Br}^{-}$and single-chain surfactant DTAB have been carried out. Fluorescence measurements indicate that the hydrophobic interaction plays a major role in unfolding the BSA verified that the electrostatic interaction pays an important role of in controlling the overall formation of the BSAsurfactant assembly. Those results show that there is a cooperation of electrostatic interaction and hydrophobic interaction for surfactants/BSA system in controlling the protein formation. For both the electrostatic interaction and hydrophobic interaction, the trimeric surfactants are expected to be stronger than corresponding 
Gemini surfactants and single-chain surfactants, the former are more efficient as protein denaturants than the latter. The results show that the aggregation degree of surfactant has a significant effect on the conformational changes of BSA. It is suggested that the synthesized trimeric surfactants can prove as effective tools for the refolding of proteins. In future, these findings can be used as a model to study other such systems and broaden their application in the fields of pharmaceuticals, cosmetics, biochemistry.

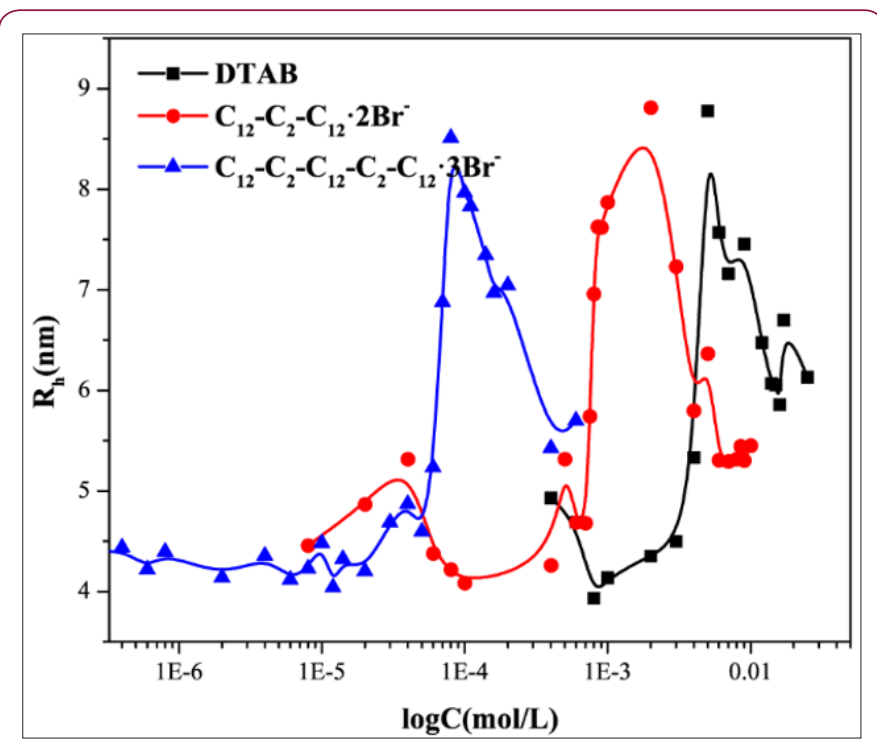

Figure 3: The variation of hydrodynamic radius of BSA/ surfactant complex with concentration of different surfactants at $\mathrm{PH}=7.4$ and $289.15 \mathrm{~K}$.

\section{Acknowledgment}

This work is supported by the National Natural Science Foundation of China (Project No. 21476072) and the Fundamental Research Funds for the Central Universities

\section{References}

1. XG Liu, XJ Xing, ZN Gao (2014) Synthesis and physicochemical properties of star-like cationic trimeric surfactants, Colloids and Surfaces A: Physicochemical and Engineering Aspects 457: 374-381.

2. MUH Mir, JK Maurya, S Ali, S Ubaid-ullah, AB Khan, et al. (2014) Molecular interaction of cationic gemini surfactant with bovine serum albumin: A spectroscopic and molecular docking study. Process Biochemistry 49: 623-630.

3. C Bombelli, L Giansanti, P Luciani, G Mancini (2009) Gemini Surfactant Based Carriers in Gene and Drug Delivery. Current Medicinal Chemistry 16(2): 171-183.

4. M Mishra, P Muthuprasanna, KS Prabha, PS Rani, IA Satish, et al. (2009) Basics and potential applications of surfactants-a review.

5. DJ Mc Clements (2015) Food emulsions: principles, practices and techniques. CRC press pp. 352-690.

6. HJ Lee, A McAuley, KF Schilke, J McGuire (2011) Molecular origins of surfactant-mediated stabilization of protein drugs. Advanced drug delivery reviews 63(13): 1160-1171.

7. M Akram, IA Bhat, S Anwar, D Kabir UD (2016) Biophysical analysis of novel oxy-diester hybrid cationic gemini surfactants (Cm-E2O-Cm) with xanthine oxidase (X0). Process Biochemistry 51(9): 1212- 1221.
8. T Zhou, MQ AO, GY Xu, T Liu, J Zhang, et al. (2013) Interactions of bovine serum albumin with cationic imidazolium and quaternary ammonium gemini surfactants: Effects of surfactant architecture. Journal of colloid and interface science 389: 175-181.

9. A Stenstam, A Khan, H Wennerström (2001) The lysozyme-dodecyl sulfate system. An example of protein-surfactant aggregation. Langmuir : the ACS journal of surfaces and colloids 17: 7513-7520.

10. PN Moore, S Puvvada, D Blankschtein (2013) Role of the Surfactant Polar Head Structure in Protein-Surfactant Complexation: Zein Protein Solubilization by SDS and by SDS/C12E n Surfactant Solutions. Langmuir : the ACS journal of surfaces and colloids 19: 1009-1016.

11. CM Dobson (1999) Protein misfolding, evolution and disease. Trends in biochemical sciences 24: 329-332.

12. HM Kwaambwa, AR Rennie (2012) Interactions of surfactants with a water treatment protein from Moringa oleifera seeds in solution studied by zeta-potential and light scattering measurements. Biopolymers 97: 209-218.

13. M Jones (1992) Surfactant interactions with bio membranes and proteins. Chem Soc Rev 21: 127-136.

14. N Gull, P Sen, RH Khan, D Kabir ud (2009) Interaction of Bovine (BSA), Rabbit (RSA), and Porcine (PSA) Serum Albumins with Cationic SingleChain/Gemini Surfactants: A Comparative Study. Langmuir : the ACS journal of surfaces and colloids 25: 11686-11691.

15. XW Yajuan Li, Yilin Wang (2006) Comparative Studies on Interactions of Bovine Serum Albumin with Cationic Gemini and Single-Chain Surfactants.

16. Y Wang, R Guo, J Xi (2009) Comparative studies of interactions of haemoglobin with single-chain and with gemini surfactants. Journal of colloid and interface science 33: 470-475.

17. G Vignesh, S Nehru, Y Manojkumar, S Arunachalam (2014) Spectroscopic investigation on the interaction of some surfactant-cobalt(III) complexes with serum albumins. Journal of Luminescence 145: 269-277.

18. J Xiao, J Cai, X Guo (2013) Reverse micellar extraction of bovine serum albumin - a comparison between the effects of gemini surfactant and its corresponding monomeric surfactant. Food Chem 136: 1063-1069.

19. S Ghosh, J Dey (2015) Interaction of bovine serum albumin with $\mathrm{N}$-acyl amino acid based anionic surfactants: Effect of head-group hydrophobicity. Journal of colloid and interface science 458: 284-292.

20. YS Ge, SX Tai, ZQ Xu, L Lai, FF Tian, et al. (2012) Synthesis of three novel anionic gemini surfactants and comparative studies of their assemble behavior in the presence of bovine serum albumin. Langmuir: the ACS journal of surfaces and colloids 28: 5913-5920.

21. M Kumari, JK Maurya, UK Singh, AB Khan, M Ali, P Singh, et al. (2014) Spectroscopic and docking studies on the interaction between pyrrolidinium based ionic liquid and bovine serum albumin, Spectrochimica acta. Molecular and biomolecular spectroscopy 124 : 349-356.

22. Y Pi, Y Shang, C Peng, H Liu, Y Hu, et al. (2006) Interactions between bovine serum albumin and gemini surfactant alkanediyl- $\alpha, \omega$-bis (dimethyldodecyl-ammonium bromide). Biopolymers 83: 243-249.

23. F Menger, C Littau (1993) Gemini surfactants: a new class of selfassembling molecules. Journal of the American Chemical Society 115: 10083-10090.

24. R Zana (2002) Dimeric and oligomeric surfactants. Behavior at interfaces and in aqueous solution: a review. Advances in colloid and interface science 97: 205-253.

25. A Papadopoulou, RJ Green, RA Frazier (2005) Interaction of flavonoids with bovine serum albumin: a fluorescence quenching study. Journal of Agricultural and Food Chemistry 53: 158-163. 
26. C Dufour, O Dangles (2005) Flavonoid-serum albumin complexation: determination of binding constants and binding sites by fluorescence spectroscopy. Biochimica et Biophysica Acta (BBA)-General Subjects 1721: 164-173.

27. PK Misra, U Dash, S Maharana (2015) Investigation of bovine serum albumin-surfactant aggregation and its physicochemical characteristics. Colloids and Surfaces A: Physicochemical and Engineering Aspects 483: 36-44.

28. M In, V Bec, O Aguerre-Chariol, R Zana (2000) Quaternary ammonium bromide surfactant oligomers in aqueous solution: self-association and microstructure. Langmuir : the ACS journal of surfaces and colloids 16: 141-148.

29. L Yue, Y Wang, Z He, J Chen, Y Shang, et al. (2015) Effect of ionic liquid C2mimBr on rheological behavior of Gemini surfactant 12-2-12 aqueous solution. Colloid Polym Sci 293: 2373-2383.

30. P Bharmoria, KS Rao, TJ Trivedi, A Kumar (2014) Biamphiphilic ionic liquid induced folding alterations in the structure of bovine serum albumin in aqueous medium. The journal of physical chemistry. B 118: 115-124.

\section{ISSN: 2574-1241}

DOI: 10.26717/BJSTR.2018.07.001542

Yazhuo Shang. Biomed J Sci \& Tech Res

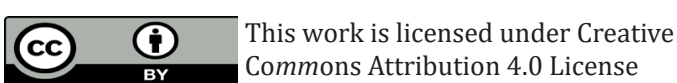

Submission Link: https://biomedres.us/submit-manuscript.php

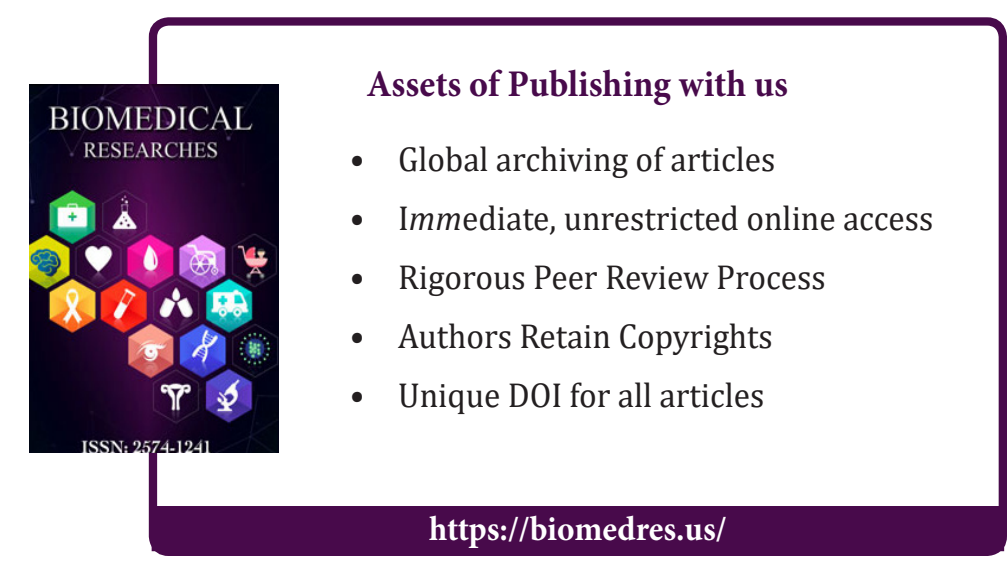

